\title{
RELATION OF DEAF PERSONS TOWARDS BILINGUALISM AS COMMUNICATION MODE
}

\section{Naim Salkić1}

Centre for hearing and speaking rehabilitation Sarajevo

Received: 20.12.2012

Accepted: 14.02.2013
Original scientific paper

UDC: 81'221.24:81'246.2-056.263

\begin{abstract}
Bilingualism of a deaf child implies concurrent cognition and usage of sign language, as community language and oral-voice language as language of greater community in which deaf persons live. Today, most authors consider that deaf persons should know both of these languages and that deaf persons need to be educated in both languages, because of their general communication and complete psycho-social development. Through research on sample of 80 deaf examinees, we affirmed the kind of relation that deaf persons have towards bilingualism, bilingual way of education and communication. The research results have shown that bilingualism and bilingual way of education and communication is acceptable to deaf persons and that there is no statistically significant difference between the sub-samples of examinees.
\end{abstract}

Keywords: bilingualism, sign language, oral-voice speech and language

\section{INTRODUCTION}

Bilingualism of hearing persons implies cognition of two languages which have speech and writing form (Kangas, 1991). Bilingualism of a deaf child implies cognition of sign language, as community language of deaf persons and oralvoice language as language of greater community in which deaf persons live (Grosjean, 1997). Bilingual communication of deaf persons represents concurrent cognition and usage of two communication systems, oral-voice speech and language and sign language. Oral-voice speech and language represents the standard way of communication among persons. Sign language is the first and natural language of deaf persons (Grosjean, 1997, Bradarić-Jončić 2000). Since deaf per- sons live in hearing world and since they have the need to communicate with hearing persons, they are forced to learn the language of hearing persons and to communicate in this language. It is doubtless that deaf persons should learn the language of hearing persons and use it, but it is also at the same time doubtless that deaf persons should use their standard way of communication, sign language (Kurtagić, Hasanbegović, 2004). Deaf persons, due to hearing loss, are not able to spontaneously learn oral-voice speech and language, but they are forced to learn it systematically, through special methods and procedures, during their educational-rehabilitation process (Hasanbegović, Salkić, Mahmutović 2009).

${ }^{1}$ Correspodence to:

Naim Salkić, Centre for hearing and speaking rehabilitation Sarajevo

Sarajevo, Bosnia and Herzegovina

Phone: +38761 193291

E-mail: salkicnaim@yahoo.com 
Even besides system learning of oral-voice speech and language, which is necessary for them due to their communication interactions with the hearing environment in which they live, deaf persons still actualize their communication within population through sign language. In that way, they marginalize oral-voice language, which complicates the final aim of education and rehabilitation (Hasanbegović, Salkić, Mahmutović 2009). The level of adoption of the one, the other or both languages varies from case to case. In final, some children will be more skilled in communication through sign language, other in communication through oral-voice language, and some will be bilingual and communicate through both, sign and oral-voice speech and language. Today, most authors consider that deaf persons should know both languages and that deaf person should be educated in both languages, because of their general communication and complete psycho-social development. What is the relation of deaf persons towards bilingual way of communication as communication system which includes sign language as their first and natural language and oral-voice speech and language as the language of hearing community in which deaf persons live?

Research aim: Examine the relation of deaf persons towards bilingual communication system and bilingual way of communication and determine whether there is a statistically significant difference between the two sub-samples of examinees.

In accordance with the set aim, it was assumed that deaf examinees have positive relation towards bilingual communication system and bilingual way of communication, and that the two sub-samples of examinees are statistically significantly different in relation towards bilingualism and bilingual way of communication.

\section{METHODS OF WORK}

\section{Sample of examinees}

The research is done on sample of 80 examinees, which are, for the needs of affirming of importance of differences in relation towards bilingualism and bilingual way of communication, divided into two sub-samples. First sub-sample was composed of deaf examinees who have, during their educational rehabilitation procedure and in their education and rehabilitation, been using oral-voice method as dominant method of adoption of knowledge, and partly sign method $(\mathrm{N}=40)$. Second subsample was composed of examinees who have, as per the same, oral-voice method of education and rehabilitation, finished that process and who live and work in the environment of the hearing, and who, as means of communication, use language as per their personal choice, sign, oral-voice or concurrently both $(\mathrm{N}=40)$.

\section{Measuring instrument}

For the needs of the research, a measuring instrument is formed (questionnaire) which consists of 6 variables which define the relation of deaf examinees towards bilingualism and bilingual education and communication. The measuring of results was done as per Likert's type of scale, composed of three categories of answers (YES, YES/NO and NO).

\section{Sample of variables}

1. I like to know and use the language of the hearing and the deaf.

2. I am glad when the hearing people speak in gestures, it eases the learning of the language of the hearing.

3. I often talk to the deaf and hearing people.

4. I talk more to the deaf than to the hearing persons.

5. I prefer to talk to deaf persons to the hearing ones.

6. I do not like to speak to hearing people at all.

\section{Methods of data processing}

For data analysis, a method of descriptive and discrimination analysis is used. The basic statistical parameters, frequencies and percentages are calculated and it is affirmed whether statistically significant difference between the two sub-samples of examinees exists. Collected data is processed in statistical package SPSS 12.0 for Windows. 


\section{RESULTS AND DISCUSSION}

From table 1, it can be concluded that affirmative answers range from $47,50 \%$ to $90 \%$, neutral from $1,25 \%$ to $30 \%$, and negative from $2,50 \%$, to $30 \%$. From the content of variable 1 , we can see that $72,50 \%$ of deaf examinees likes to know and uses both, oral-voice and sign language, which takes us into conclusion that most deaf persons accept and have positive attitude towards bilingualism, bilingual education and communication and that it eases for them to learn oral-voice speech and language. This conclusion is confirmed by the answers of examinees on variable 2 , from which we can conclude that $88,75 \%$ of examinees are affirmatively related to assertion that they are glad that hearing people speak through gestures and that it makes it easier for them to learn the language of the hearing people and eases communication. The answers of examinees in variable 3 show that $51,25 \%$ of examinees often talk to both, deaf and hearing people, which takes us into conclusion that deaf persons, during their daily activities, use both languages and that they have positive relation towards bilingualism and bilingual way of communication. From the content of variable 4 , it is noticeable that $90 \%$ of examinees talk more to the deaf than to the hearing people, and $77,50 \%$ of examinees prefer to talk to the deaf than to the hearing people which is shown by variable 5, which we expected, since there is a better cognition of sign language in relation to oral-voice, and resorting of deaf persons to sign language as their natural and, for them, easier language. Variable 6, however, shows that most examinees of 52,50 $\%$ is either neutral or denies assertion that they do not like to talk to the hearing people at all. On basis of analysis of frequencies and percentages of answers of deaf examinees on set assertions, it can be concluded that deaf examinees accept bilingualism and bilingual way of communication, and that they consider that bilingualism is making it easier for them to learn oral-voice language and communicate with the hearing people.

Table 1 Distribution of frequencies and percentages of answers of the total sample of examinees as per particular variables

\begin{tabular}{|c|c|c|c|c|c|c|c|}
\hline \multirow{2}{*}{ VARIABLES } & \multicolumn{2}{|c|}{ YES } & \multicolumn{2}{|c|}{ YES/NO } & \multicolumn{2}{|c|}{ NO } & \multirow{2}{*}{$\underset{\tilde{\sigma}}{0}$} \\
\hline & $\mathbf{f}$ & $\%$ & $\mathbf{f}$ & $\%$ & $\mathbf{f}$ & $\%$ & \\
\hline 1. & 58 & 72,50 & 17 & 21,25 & 5 & 6,25 & 80 \\
\hline 2. & 71 & 88,75 & 7 & 8,75 & 2 & 2,50 & 80 \\
\hline 3. & 41 & 51,25 & 24 & 30,00 & 15 & 18,75 & 80 \\
\hline 4. & 72 & 90,00 & 1 & 1,25 & 7 & 8,75 & 80 \\
\hline 5. & 62 & 77,50 & 9 & 11,25 & 9 & 11,25 & 80 \\
\hline 6. & 38 & 47,50 & 18 & 22,50 & 24 & 30,00 & 80 \\
\hline TOTAL & 342 & $71,25 \%$ & 76 & $15,83 \%$ & 62 & $12,91 \%$ & \\
\hline
\end{tabular}




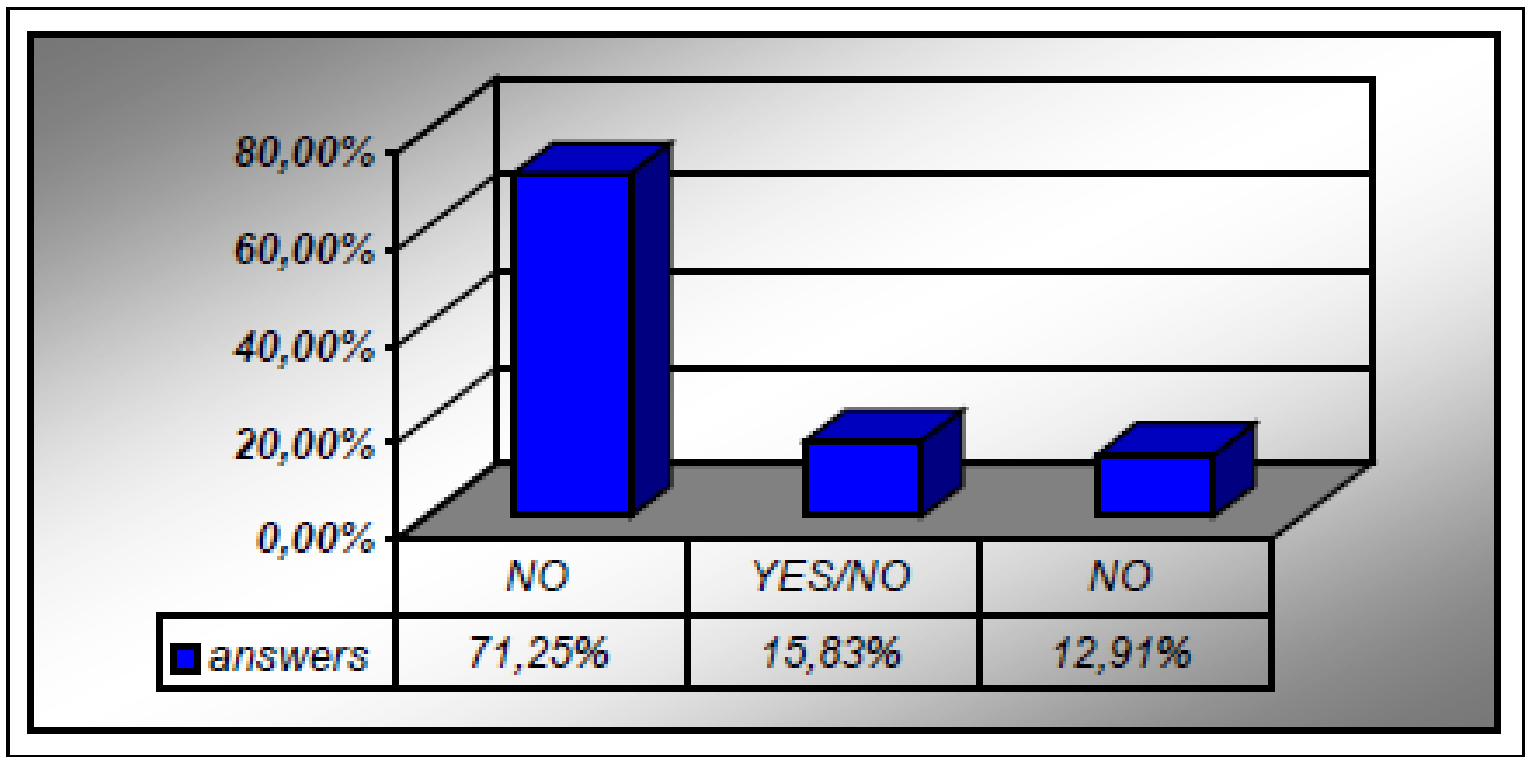

Graph 1. Distribution of percentages of the answers of the total sample of deaf examinees as per all variables

Graph 1 shows that the largest percentage of examinees, $71,25 \%$ of them, related positively to bilingualism and bilingual way of communication and that they do not have anything against cognition and appliance of oral-voice and sign language and that they consider that bilingualism and bilingual education is helping them to learn oral-voice speech and language and by that makes it easier for them to communicate and socially integrate. Neutral answers amount to $15,83 \%$, and $12,91 \%$ of examinees replied negatively.

\section{Analysis of frequencies and percentages of the} two sub-samples of examinees

Comparative analysis of frequencies and percentages of answers of the two sub-samples of deaf examinees (Table 2), shows that both sub-samples have, in large percentage, a positive relation to set assertions from the content of variables, and it can globally be concluded that bilingualism and bilingual way of education and communication is absolutely acceptable as for the population of deaf persons who are in the educational-rehabilitation process and who are daily exposed to oral-voice education and communication, and partly sign one, so for the grown-up deaf persons who have completed this process and who live and work in the environment of the hearing persons. Also, from the frequencies and percentages of the answers of the one and other group of examinees we can conclude that there are certain differences in answers on set assertions. Those differences are most probably the result of the influence of oral-voice method as the dominant method in the process of regular educational rehabilitation activities with the first group of examinees, and free choice of learning and using of the one, the other or both languages with grown-up deaf persons who have finished their education and who, as per their own choice, use one, the other or both modes of communication.

Table 2 Comparison of distribution of frequencies and percentages of answers of the sub-sample of examines as per particular variables

\begin{tabular}{|c|c|c|c|c|c|c|c|c|c|c|c|c|}
\hline \multirow[t]{2}{*}{ VARIABLES } & \multicolumn{4}{|c|}{ YES } & \multicolumn{4}{|c|}{ YES/NO } & \multicolumn{4}{|c|}{ NO } \\
\hline & I & II & I & II & I & II & I & II & I & II & I & II \\
\hline & f & f & $\%$ & $\%$ & f & f & $\%$ & $\%$ & f & $\mathbf{f}$ & $\%$ & $\%$ \\
\hline 1. & 25 & 33 & 62,50 & 82,50 & 10 & 7 & 25,00 & 17,50 & 5 & 0 & 12,50 & 0,00 \\
\hline 2. & 38 & 33 & 95,00 & 82,50 & 0 & 7 & 0,00 & & 2 & 0 & 5,00 & 0,00 \\
\hline 3. & 18 & 23 & 45,00 & 57,50 & 15 & 9 & 37,50 & 22,50 & 7 & 8 & 17,50 & 20,00 \\
\hline 4. & 35 & 37 & 87,50 & 92,50 & 0 & 1 & 0,00 & 2,50 & 5 & 2 & 12,50 & 5,00 \\
\hline 5. & 33 & 29 & 82,50 & 72,50 & 1 & 8 & 2,50 & 20,00 & 6 & 3 & 15,00 & 7,50 \\
\hline 6. & 21 & 17 & 52,50 & 42,50 & 6 & 12 & 15,00 & 30,00 & 13 & 11 & 32,50 & 27,50 \\
\hline TOTAL & 170 & 172 & $70,83 \%$ & $71,66 \%$ & 32 & 44 & $13,33 \%$ & $18,33 \%$ & 38 & 24 & $15,83 \%$ & $10 \%$ \\
\hline
\end{tabular}




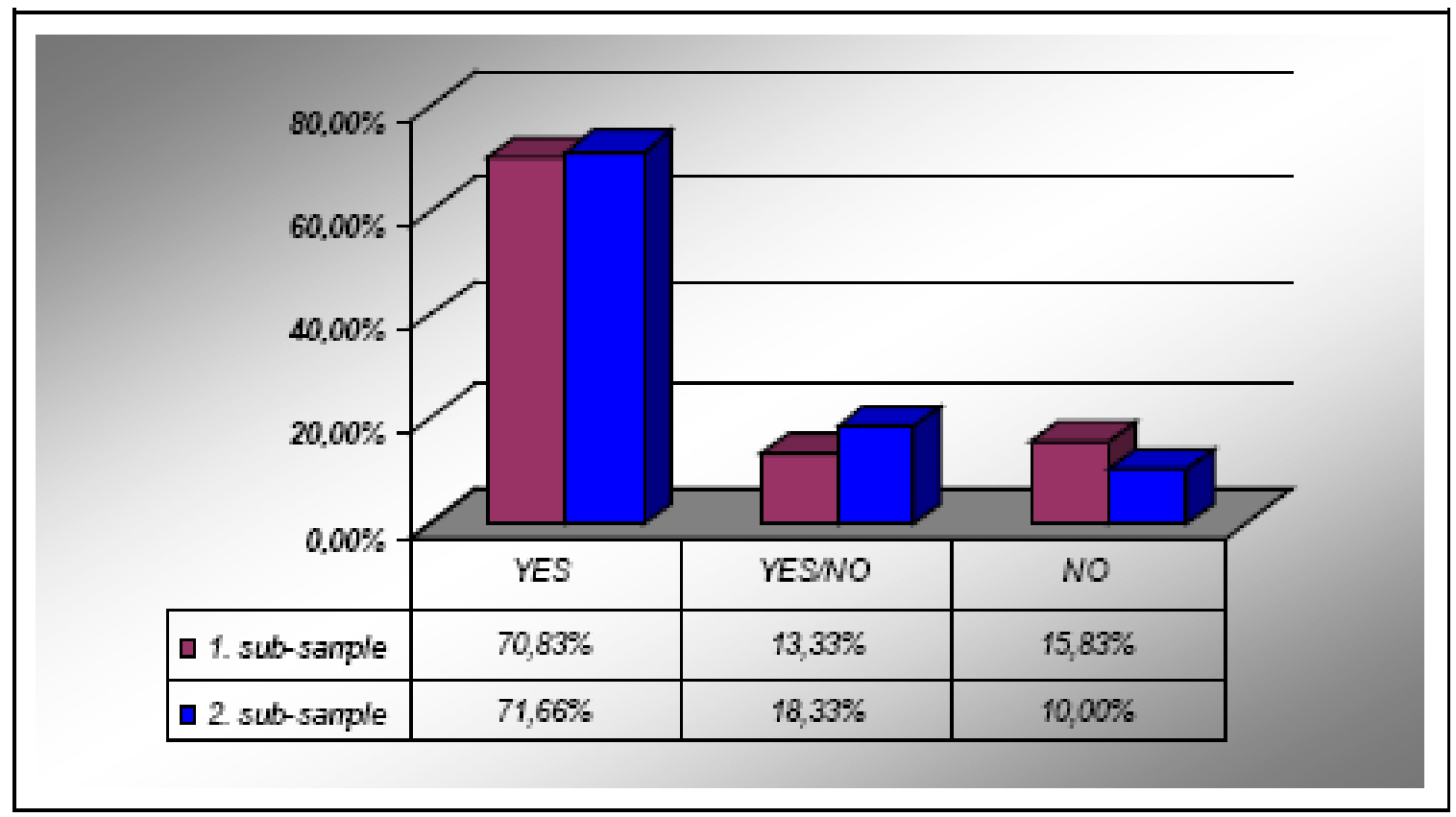

Graph 2 Comparison of distribution of percentage of answers of the two subsamples of deaf examines as per all variables

Graph 2 shows comparison of distribution of answers of the two sub-samples of deaf examines towards bilingualism as way of education and communication. Largest percentage of examinees of the first sub-sample, $70,83 \%$ of them, and $71,66 \%$ of examinees of the second sub-sample related positively towards bilingualism and bilingual way of education and communication, and therefore we can conclude that bilingualism and bilingual education and communication is absolutely acceptable for both groups of examinees.

\section{Discrimination analysis}

Through discrimination analysis we tried to determine whether there is a statistically significant difference between the two sub-samples of examinees in relation towards bilingualism and bilingual way of education and communication. Statistical importance of differences between the sub-samples of unique sample of deaf examinees is determined on level of 0,01 . On basis of strength of discrimination, standard deviation of examined groups, the $\mathrm{x} 2$ test, freedom level and statistical importance level of 0,01 , it is ascertained that the two sub-samples of examinees are not statistically significantly different. Since, in descriptive analysis, certain differences in frequencies and percentages of answers of examinees are noticeable, and by discrimination analysis it is ascertained that they are not statistically significantly important on level of importance of 0,01 , in further analysis we identified which variables are the ones that mostly, and on what level of importance, are discriminating the two subsamples of examinees.

Table 3 Statistical importance of variability of inter-group meanss with Lambda, F test of importance and Canonical coefficient discrimination functions

\begin{tabular}{ccccc}
\hline Variables & L & F & $\begin{array}{c}\text { Coeff. discrim. } \\
\text { function }\end{array}$ & P \\
\hline 1 & 0,96 & 3,31 & $-0,39$ & 0,07 \\
$\mathbf{2}$ & $\mathbf{0 , 9 3}$ & $\mathbf{5 , 6 2}$ & $\mathbf{0 , 7 3}$ & $\mathbf{0 , 0 2}$ \\
3 & 0,97 & 1,97 & $-0,24$ & 0,16 \\
4 & 0,99 & 0,90 & 0,52 & 0,75 \\
5 & 0,96 & 3,43 & 0,33 & 0,07 \\
6 & 0,97 & 1,96 & 0,05 & 0,16 \\
\hline
\end{tabular}


Table 3 shows that variable number 2 is discriminating two sub-samples of examinees on level of statistical importance of 0,05 , which we can correlate with certain differences in frequencies and percentages of answers of examinees. Other variables do not statistically significantly differ the two sub-samples even on level of statistical importance of 0,05 .

On basis of descriptive analysis of frequencies and percentages of replies of deaf examinees, assumption, that deaf examinees have positive relation towards bilingualism, bilingual education and communication, we can with certainty confirm, because $71,25 \%$ of examinees has affirmatively related towards set assertions of measuring instrument. Assumption, that these two sub-samples of examinees are statistically significantly different in relation to bilingualism, bilingual education and communication, we can with certainty reject, because discrimination analysis proved that there is no statistically significant difference on level of importance of 0,01 .

\section{CONCLUSIONS}

Bilingualism, bilingual way of education and communication are acceptable to deaf persons, because most examinees replied that they accept this way of education and communication and that it makes it easier for them to learn firstly oral-voice speech and language and by that also general communication and learning. Cognition and usage of gesture speech and sign language by hearing persons, and especially by teaching staff eases the learning of oral-voice speech and language for deaf persons. Positive relation towards bilingualism, bilingual education and communication of deaf person confirms, through that assertion, that most of deaf examinees talks daily to both, deaf and hearing people, but however, they state that they talk more with the deaf. Two subsamples of examinees are not statistically significantly different, which means that, bilingualism and bilingual way of education and communication is acceptable even for population of deaf persons of school age and for population of adult deaf persons. We are of the opinion, that research must continue in this field so as to ease education and communication of the deaf.

\section{REFERENCE}

Bradarić-Jončić, S. (2000). Manuelna komunikacija osoba oštećena sluha [Manual communication of persons with hearing damage]. Hrvatska revija za rehabilitacijska istraživanja, 36, 2. Zagreb, Croatia.

Grosjean, F. (1997) The right of a deaf child to grow-up bilingually. http://www.crodeafweb.net/text/ grosjean.htm Hasanbegović, H. (2009). Uvod u rehabilitaciju slušanja i govora [Introduction into rehabilitation of hearing and speaking]. Tuzla, BiH: Of-set Tuzla.

Hasanbegović, H., Salkić, N, Mahmutović, E. (2009). Odnos gluhih osoba prema oralno-glasovnom govoru i jeziku [Relation of deaf persons towards oral-voice speech and language]. Defektologija, 15, 1, 47-52. Tuzla, B\&H: Edukacijsko-rehabilitacijski fakultet.

Hasanbegović, H., Mahmutović, E., Salkić, N. (2008). Competences of experts in integrative processes of deaf children. Uluslararasi Sosyal Arastirmalar Dergisi, The Journal of International Social research. 1/5. pp. 372 - 378 Kangas, S.T. (1991). Bilingualism. Belgrade, Serbia: Zavod za udžbenike i nastavna sredstva.

Kurtagić, I., Hasanbegović, H., Salkić, N. (2006). Neuropsihološki osvrt na govorno-jezični razvoj gluhe djece. [Neuron-psichological review on speech-language development of deaf children]. Defektologija, 2006; 9 (2), pp. 265 -369. Tuzla, B\&H. Edukacijsko-rehabilitacijski fakultet Tuzla.

Kurtagić, I., Hasanbegović, H. (2004). Procesi učenja govora i jezika kod gluhih u postoperativnoj rehabilitaciji programske postavke [The processes of learning speech and language with the deaf in post-operational rehabilitation - program settings]. Defektologija. 11. Tuzla, B\&H: Edukacijsko-rehabilitacijski fakultet Tuzla. 